\title{
PERAN PEMERINTAH DAERAH DALAM IMPLEMENTASI KURIKULUM 2013
}

\section{THE LOCAL GOVERNMENT'S ROLE IN THE IMPLEMENTATION OF CURRICULUM 2013}

\author{
Lucia H. Winingsih \\ Pusat Penelitian Kebijakan, Balitbang, Kemendikbud \\ Gedung E Lantai 19, Jl. Jenderal Sudirman, Senayan, Jakarta Pusat \\ e-mail: luciahw@yahoo.com
}

Naskah diterima tanggal: 22/09/2015, Direvisi akhir tanggal: 10/01/2016, disetujui tanggal: 14/03/2016

\begin{abstract}
The purpose of the study was to examine the local's government role in implementing the newly Curiculum 2013, in particular related to the role in: (1) sosialization;

(2) training for teachers, pricipal, and school supervisor; (3) providing and distribution of the books; (4) financing; and (5) monitoring and evaluation of the implementation of Curriculum 2013. The study used qualitative method, and used focus group discussion (FGD) in data collection. Descriptive Analysis used to explain the result of the study. The study shows that (1) Budget for the Curriculum 2013 is not provided by the local government so that they cannot socialize the curriculum formally;(2) though in the curriculum implementation their role is as only the coordinator, their role is increasing in financing by allocating fund for principal and teacher training ; (3) local government has important role in providing and distributing the books by supplying $C D$ to substitute the books since the books were significantly delayed to reach the area; (4) most of the local government has improved their role in financing the implementation of curriculum, particularly for the financing of teachers training; and (5) the local government has very limited role for the monitoring and evaluation because the process of the implementation of Curriculum 2013 was still going on, also the competencies of the local actors for monitoring and evaluation is still needed to improve. The study concludes that the local governments do not have significant role in the beginning of the implementation of Curriculum 2013.
\end{abstract}

Keywords: curriculum 2013, teacher training, local government role, curriculum implementation.

\begin{abstract}
Abstrak: Tujuan dari penelitian ini untuk mengkaji peran pemerintah daerah dalam pengimplementasian Kurikulum 2013, terutama terkait dengan (1) sosialisasi, (2) pendidikan dan pelatihan (diklat) guru, kepala sekolah dan pengawas, (3) pengadaan dan distribusi buku, (4) pendanaan, dan (5) monitoring dan evaluasi. Penelitian menggunakan metode kualitatif, data dikumpulkan dengan cara focus group discussion (FGD). Analisis data dilakukan dengan menggunakan analisis deskriptif. Hasil penelitian menunjukkan bahwa (1) pemerintah daerah pada umumnya tidak menyediakan anggaran secara khusus untuk kepentingan sosialisasi Kurikulum 2013, melakukan sosialisasi kepada guru, kepala sekola, pengawas umumnya yang disisipkan melalui berbagai kegiatan rapat dinas, workshop, seminar, pendidikan dan pelatihan, dan kegiatan-kegiatan seperti KKG, MGMP, KKS, dan forum pengawas sekolah; (2) peran pemerintah daerah dalam pendidikan dan pelatihan Kurikulum 2013 terbatas sebagai koordinator; (3) pemerintah daerah menjadi sangat berperan dalam mengatasi keterlambatan pengadaan dan distribusi buku, yaitu dengan cara memfasilitasi pengadaan compact disc (CD) pengganti buku, dan berkoordinasi dengan sekolah untuk memenuhi kebutuhan buku; (4) dalam hal pendanaan, pemerintah daerah
\end{abstract}


mulai terlibat di tahun kedua implementasi Kurikulum 2013, sebagian besar pemerintah daerah menyediakan anggaran melalui APBD dalam berbagai bentuk, sebagian besar untuk melatih guru dan yang lainnya umumnya untuk melatih kepala sekolah dan pengawas; dan (5) pemerintah daerah umumnya belum melakukan monitoring dan evaluasi terhadap implementasi Kurikulum 2013 karena selain masih dalam proses implementasi, pengetahuan pelaku monitoring dan evaluasi mengenai Kurikulum 2013 di daerah masih terbatas. Penelitian ini meyimpulkan bahwa peran pemerintah daerah masih belum signifikan dalam pengimplementasian Kurikulum 2013.

Kata kunci: kurikulum 2013, pendidikan dan pelatihan, pemerintah daerah role, implementasi kurikulum.

\section{PENDAHULUAN}

Kurikulum mempunyai peran sangat besar dalam pembangunan pendidikan karena dalam kurikulum tersebut termaktub tujuan mulia untuk anak didik yang ingin dicapai, yaitu memberikan anak didik pengetahuan, sikap dan keterampilan agar sesuai dengan kebutuhan kehidupan dan dunia kerja. Dunia kerja berubah dengan cepat sehingga kurikulum juga harus bisa mengantisipasi perubahan tersebut. Rancangan implementasi Kurikulum 2013 merupakan salah satu upaya untuk mengantisipasi perubahan tersebut. Di samping itu, pada tahun 2020 hingga 2030 Indonesia akan menikmati bonus demografi, yaitu suatu kondisi dengan komposisi jumlah penduduk usia produktif 15 - 64 tahun mencapai titik maksimal, sehingga terjadi jumlah angkatan kerja maksimal, dan bonus demografi ini akan memberikan dampak maksimal bila negara melakukan investasi sumber daya manusia (Jati, 2015). Oleh karena itu, agar Indonesia bisa menikmati bonus tersebut, pendidikan merupakan salah satu kunci untuk mempersiapkan sumber daya manusia agar berkualitas dan mampu bersaing baik pada pasar domestik, regional, maupun internasional.

Pada umumnya, reformasi atau perubahan kurikulum mengarah pada pengembangan kurikulum yang lebih baik dan berkaitan dengan upaya peningkatan mutu pendidikan. Dalam pengembangan kurikulum biasanya akan tercipta pengetahuan yang akan menghasilkan bahanbahan instruksi yang baru (Clements, 2007), yang berkembang dari waktu ke waktu menyesuaikan perubahan yang terjadi. Perubahan kurikulum juga dimaksudkan untuk meningkatkan mutu pendidikan di Indonesia. Hasil tes Programme for International Student Assessment (PISA) tahun 2012 menunjukkan bahwa mutu pendidikan di Indonesia masih rendah karena Indonesia berada pada peringkat 64 dari 65 negara yang mengikuti tes tersebut. Sementara Singapura berada pada urutan ke2, Jepang pada urutan ke-7 dan, Malaysia pada urutan ke-52. Hal ini menunjukkan bahwa prestasi siswa Indonesia Indonesia masih tertinggal jauh dalam ilmu pengetahuan, matematika dan kemampuan membaca dengan negara tetangga. Hanya 5\% siswa Indonesia yang mampu mengerjakan soal kategori tinggi yang memerlukan penalaran dibandingkan dengan siswa Korea yang mampu mencapai $71 \%$. Sebaliknya, $78 \%$ siswa Indonesia dapat mengerjakan soal berkategori rendah yang memerlukan hafalan dibanding dengan 10\% siswa Korea yang mengerjakan soal tersebut. Alasan lain adalah bahwa kekuatan ekonomi Indonesia pada tahun 2030 ditargetkan untuk mencapai peringkat tujuh dunia sehingga perlu persiapan sumber daya manusia yang tangguh dan memiliki kompetensi yang unggul. Masih ada tantangan-tantangan lain yang harus dihadapi oleh bangsa Indonesia, yaitu terkait dengan arus globalisasi dan berbagai isu yang terkait dengan masalah lingkungan hidup, kemajuan teknologi dan informasi, kebangkitan industri kreatif dan budaya, dan perkembangan pendidikan di tingkat internasional, yang semua itu membutuhkan 
sumber daya manusia yang handal untuk meresponnya.

Oleh karena itu, ada berbagai aspek yang harus dipersiapkan agar implementasi Kurikulum 2013 dapat mencapai target sasaran pembelajaran yang ditetapkan oleh pemerintah. Implementasi Kurikulum 2013 merupakan salah satu kebijakan pendidikan yang besar yang bersifat nasional karena melibatkan berbagai pemangku kepentingan (stakeholdes), seperti guru, kepala sekolah, pengawas, dinas pendidikan di daerah, dan sekolah serta peserta didik, dalam jumlah yang cukup besar maka diperlukan pengelolaan yang bisa menggerakkan stakeholders tersebut dengan efektif dan efisien. Target pencapaian sasaran pada tingkat satuan pendidikan direncanakan untuk dilakukan secara bertahap yang penerapannya telah dimulai pada tahun 2013, dan direncanakan akan diteruskan pada tahun 2014, 2015 hingga 2019.

Implementasi Kurikulum 2013 ini merupakan upaya strategis peningkatan mutu pendidikan yang memerlukan dukungan sumber daya yang sangat besar, yaitu antara lain dana, sumber daya manusia, fasilitas dan kerja sama, koordinasi pemerintah, pemerintah daerah dan pihak-pihak yang berkepentingan lainnya agar pada tahun 2017 secara nasional seluruh kelas di setiap satuan pendidikan berstatus negeri maupun swasta telah melaksanakan Kurikulum 2013. Pada tahun 2013, Pemerintah Pusat telah menyiapkan dana yang diperlukan terutama untuk pengadaan dan pendistribusian buku melalui APBN dan pengalokasian melalui dana alokasi khusus (DAK) serta bantuan operasional sekolah (BOS) di setiap satuan pendidikan. Pemerintah juga melaksanakan program pelatihan berjenjang untuk 1,7 juta guru, pengawas, dan kepala sekolah. Bersamaan dengan itu, Pemerintah juga melakukan sosialisasi serta koordinasi dengan seluruh pemerintah provinsi serta pemerintah Kabupaten kota/kabupaten agar implementasi kurikulum dapat dilaksanakan secara lancar dan mencapai sasaran.
Dalam kerangka desentralisasi pendidikan, sektor pendidikan merupakan kewenangan dan tanggung jawab pemerintah daerah kabupaten/ kota sebagai daerah otonom (Sucipto, 2015), peran pemerintah daerah dalam pelaksanan Kurikulum 2013 merupakan keniscayaan. Pada saat ini belum diketahui secara komprehensif tentang bagaimana peran pemerintah daerah tersebut dalam implementasi kurikulum 2013 yang merupakan kebijakan pemerintah secara nasional. Jawaban terhadap permasalahan tersebut bisa menjadi masukan bahan rumusan kebijakan dalam rangka meningkatkan peran pemerintah daerah dalam implementasi Kurikulum 2013. Oleh sebab itu, kajian tentang peran pemerintah daerah penting untuk diungkap, terutama untuk menggali dan menganalisis peran pemerintah daerah dalam implementasi Kurikulum 2013. Kajian ini semakin diperlukan mengingat era otonomi daerah merupakan ujung tombak dalam pembangunan sektor publik, sehingga tanggung jawab pemerintah daerah menjadi strategis, dan tingkat keberhasilannya akan ditentukan oleh kemampuan sumber daya manusia di daerah, pendanaan, fasilitas dan sosial budaya serta geografis setiap pemerintah daerah.

Tujuan studi ini untuk mengkaji peran pemerintah daerah kabupaten/kota dalam implementasi Kurikulum 2013, yang meliputi: 1) sosialisasi, 2) pendidikan dan pelatihan guru, kepala sekolah dan pengawas, 3) pengadaan dan distribusi buku, 4) pendanaan, dan 5) monitoring dan evaluasi pelaksanaan Kurikulum 2013.

\section{KAJIAN LITERATUR \\ Pembagian Kewenangan Pusat dan Daerah dalam Pelaksanaan Kurikulum 2013}

Dalam implementasi Kurikulum 2013, ada dua aspek yang signifikan yang menjadi perhatian banyak pihak, yaitu 1) pengadaan dan pendistribusian buku, dan 2) pendidikan dan pelatihan serta pendampingan guru, kepala sekolah dan pengawas. Terkait dengan 
pengadaan buku untuk Kurikulum 2013, diperlukan 254 judul buku dan didistribusikan sampai ke siswa tanpa dipungut biaya. Tahun anggaran 2013 pengadaan buku seluruhnya dibiayai dari APBN. Namun, pada tahun anggaran 2014 buku dicetak secara lelang dan sekolah/ satuan pendidikan harus membeli. Dana yang digunakan untuk membeli buku tersebut berasal dari dana bantuan operasional sekolah (BOS) karena $10 \%$ dari dana BOS di sekolah bisa digunakan untuk membeli buku semester 1 , sedangkan buku semester 2 bisa dibeli dengan dana alokasi khusus (DAK). Sementara itu, berkaitan dengan diklat guru/kepala sekolah/ pengawas, sasaran yang dilatih adalah 1,7 juta guru, kepala sekolah dan pengawas secara bertahap dan harus dijamin seluruh guru tuntas dilatih pada tahun 2015.

Dalam rangka menjamin keberhasilan Kurikulum 2013, diperlukan dukungan dan peran semua pihak sesuai dengan kewajiban, tanggung jawab, dan kewenangan masingmasing pihak. Pemerintah pusat, pemerintah provinsi serta pemerintah kota/kabupaten masing-masing memiliki kewajiban, tanggung jawab, dan kewenangan untuk keberhasilan pelaksanaan Kurikulum 2013. Berdasarkan Peraturan Menteri Pendidikan dan Kebudayaan Nomor 81A Tahun 2013 tentang Implementasi Kurikulum, diketahui peran dan kewajiban Pemerintah (Kemdikbud, 2013), pemerintah provinsi, serta pemerintah kabupaten.

Pertama, Kemdikbud berkewajiban menyiapkan anggaran penyiapan naskah buku dan pencetakan melalui lelang. Selain itu, Kemdikbud memberikan pelatihan kepada guru sasaran dan kepala sekolah mengenai penerapan Kurikulum 2013 serta penyiapan materi, bimbingan teknis pendampingan, dan monitoring evaluasi yang harus selesai pada bulan Juli 2014.

Kedua, pemerintah daerah tingkat provinsi berkewajiban untuk 1) mengoordinasikan pemerintah kabupaten/kota yang tidak mendapatkan DAK bidang pendidikan untuk menyiapkan anggaran penggandaan dan distribusi buku semester 2 sampai ke sekolah untuk kelas I, II, IV, V, VII, VIII, X, dan XI; 2) menyiapkan dukungan anggaran untuk pelatihan guru sasaran kelas I, II, IV, V, VII. VIII, X, dan $X I$, dan 3) bersama pemerintah daerah kabupaten/kota melaksanakan pendampingan, monitoring, dan evaluasi pelaksanaan Kurikulum 2013 di tingkat sekolah.

Ketiga, pemerintah kabupaten/kota berkewajiban untuk: 1) menyiapkan anggaran penggandaan dan pendistribusian buku semester 2 tahun pelajaran 2014/2015 sampai ke sekolah untuk kelas I, II, IV, V, VII, VIII, X, dan XI bagi pemerintah kabupaten/kota yang tidak mendapatkan DAK bidang pendidikan, 2) berkoordinasi dengan pemerintah provinsi untuk menyiapkan dukungan anggaran pelatihan guru sasaran kelas I, II, IV, V, VII, VIII, X, dan XI, dan 3) menyiapkan mekanisme teknis pendampingan, monitoring, dan evaluasi pelaksanaan Kurikulum 2013 tahun pelajaran 2014/2015 pada tingkat sekolah.

Pemerintah kabupaten/kota memiliki sejumlah kewajiban lain dalam implementasi Kurikulum 2013, yaitu melakukan koordinasi, menyiapkan anggaran, serta menyiapkan mekanisme teknis pendampingan, monitoring, dan evaluasi. Pemerintah daerah mempunyai peran yang penting untuk keberhasilan Kurikulum 2013. Namun, perlu disadari bahwa kabupaten/ kota di Indonesia amat bervariasi ditinjau dari sisi kondisi kemampuan sumber daya manusia, dana, fasilitas dan sosial budaya serta geografis. Komitmen dan dukungan dari pemerintah daerah akan mempengaruhi keberhasilan pelaksanaan Kurikulum 2013.

\section{Kebijakan Implementasi Kurikulum 2013}

Kurikulum 2013 merupakan pengembangan kurikulum berbasis kompetensi yang dirintis mulai tahun 2004, dan diteruskan pada tahun 2006. Kurikulum tersebut mulai diterapkan secara bertahap pada tahun 2013. Implementasi Kurikulum 2013 bertujuan untuk mempersiapkan peserta didik/siswa untuk menghadapi tantangan di masa depan dengan meningkatkan pengetahuan, keterampilan, keahlian dan sikap 
untuk mampu beradaptasi dan bertahan hidup di dalam lingkungan yang berubah dengan cepat (Kemdikbud, 2013), yang menuntut kemampuan adaptasi dari siswa atau masyarakat. Kurikulum 2013 dirancang untuk mempersiapkan siswa menghadapi perubahan tersebut.

Pengembangan kurikulum 2013 menitikberatkan pada beberapa pertimbangan yang berhubungan dengan Kurikulum 2006. Pertimbangan-pertimbangan tersebut yaitu antara lain: 1) konten kurikulum yang masih terlalu padat yang ditunjukkan dengan banyaknya mata pelajaran dan banyak materi yang keluasan dan tingkat kesukarannya melampaui tingkat perkembangan usia anak; 2 ) belum sepenuhnya berbasis kompetensi sesuai dengan tuntutan fungsi dan tujuan pendidikan nasional; 3) kompetensi belum menggambarkan secara holistik domain sikap, keterampilan, dan pengetahuan; beberapa kompetensi yang dibutuhkan sesuai dengan perkembangan kebutuhan (misalnya pendidikan karakter, metodologi pembelajaran aktif, keseimbangan soft skills dan hard skills, kewirausahaan) belum terakomodasi di dalam kurikulum; 4) belum peka dan tanggap terhadap perubahan sosial yang terjadi pada tingkat lokal, nasional, maupun global; 5) standar proses pembelajaran belum menggambarkan urutan pembelajaran yang rinci sehingga membuka peluang penafsiran yang beraneka ragam dan berujung pada pembelajaran yang berpusat pada guru; 6) standar penilaian belum mengarahkan pada penilaian berbasis kompetensi (proses dan hasil) dan belum secara tegas menuntut adanya remediasi secara berkala; dan 7) dengan KTSP memerlukan dokumen kurikulum yang lebih rinci agar tidak menimbulkan multi tafsir.

Kurikulum 2013 mulai diimplementasikan di sekolah-sekolah pada tahun 2013, dan terus berlanjut diterapkan di seluruh sekolah secara bertahap sampai seluruh sekolah menggunakan Kurikulum 2013. Pada tahap awal, Kurikulum 2013 mulai diterapkan oleh Kemdikbud pada tahun ajaran 2013/2014 secara bertahap dan terbatas. Pada tahap awal ini, pelaksanaan pembelajaran dengan menggunakan pola kurikulum 2013 dilakukan di 6.326 sekolah, yang terdiri dari siswa kelas I dan siswa kelas IV SD; siswa kelas VII SMP, serta siswa kelas IX SMA/ SMK. Pada tahap ke dua (Tahun 2014/2015), Kurikulum 2013 ini akan diterapkan pada siswa kelas I, II, III, IV, dan V SD; siswa kelas VII dan kelas VIII SMP; dan siswa kelas $X$ dan kelas XI SMA/SMK. Secara keseluruhan target sekolah yang menjadi sasaran untuk melaksanakan Kurikulum 2013 sejumlah 208.543 sekolah berbagai jenjang, dan target siswa sebesar 31.277.198 siswa dari berbagai jenjang satuan pendidikan (lihat Tabel 1).

Tabel 1 Jumlah Sekolah dan Siswa Sasaran Kurikulum 2013

\begin{tabular}{llrr}
\hline NO & Jenjang & Sekolah & $\begin{array}{r}\text { Siswa Kelas } \\
1,2,3,4,5,7,8\end{array}$ \\
\hline & Pendidikan Dasar & & \\
1. & SD & 148.171 & 17.640 .917 \\
2. & SMP & 35.597 & 7.107 .950 \\
3. & SMPLB & 1.744 & 32.354 \\
& Jumlah & 185.512 & 24.781 .221 \\
& & & \\
& Pendidikan Menengah & & \\
1. & SMA & 11.629 & 3.461 .096 \\
2. & SMK & 10.628 & 3.027 .467 \\
3. & SMLB & 774 & 7.414 \\
& Jumlah & 23.031 & 6.495 .977 \\
\hline Total & & 208.543 & 31.277 .198 \\
\hline
\end{tabular}

Sumber: Paparan Menteri pada Rapim Desember 2013 
Kajian ini menggunakan pendekatan kualitatif dan analisis yang digunakan bersifat deskriptif. Pengumpulan data dilakukan dengan cara atau teknik Focus Group Discussin (FGD) dan kuesioner. Pengumpulan data dilakukan antara bulan Agustus sampai dengan bulan Oktober tahun 2014. Populasi dalam penelitian ini, yaitu seluruh pemda, guru, kepala sekolah dan pengawas. Pemilihan daerah atau lokasi kajian/penelitian ini ditentukan secara purposif, yaitu didasarkan pada keterwakilan dari lembaga atau institusi yang menjadi sampel dalam kajian ini.

Pemilihan sampel penelitian didasarkan pada daerah yang menjadi sasaran piloting sejak tahun 2013 dan daerah yang telah melaksanakan Kurikulum 2013 secara mandiri. Didasarkan keterwakilan daerah maka lokasi sampel yang terpilih, yaitu Kabupaten Sleman, Kota Bengkulu, Kota Kupang, Kabupaten Gianyar, dan Kota Pontianak merupakan daerah yang menjadi sasaran piloting. Sedangkan daerah yang secara mandiri melaksanakan Kurikulum 2013 adalah Kota Malang, Kota Batam, Kabupaten Bangka Tengah, Kabupaten Kutai Kartanegara dan Kabupaten Pangkajene Kepulauan.

Responden dalam studi ini dipilih secara purposif, yaitu berdasarkan keterwakilan dari lembaga atau institusi yang menjadi sampel dalam penelitian ini. Unsur dinas pendidikan terdiri atas Kepala Seksi Kurikulum SD, SMP, SMA, dan SMK atau yang bertanggung jawab mengenai Kurikulum 2013 dan Pengawas Sekolah yang terdiri dari pengawas SD, SMP, SMA, dan SMK. Unsur sekolah terdiri atas kepala sekolah SD, SMP, SMA, dan SMK beserta guru dari sekolah yang sama yang telah melaksanakan Kurikulum 2013. Jumlah responden di masingmasing lokasi sampel tampak pada Tabel 2 .

Di setiap lokasi sampel, FGD dilakukan dalam 2 kelompok. Kelompok pertama terdiri atas narasumber yang berasal dari Pemerintah daerah, terutama dari dinas pendidikan yang mempunyai tugas dan fungsi dalam pengembangan kurikulum dan terlibat langsung dalam implementasi Kurikulum 2013, pengawas SD, SMP, SMA, dan SMK. Kelompok kedua terdiri atas seluruh kepala sekolah SD, SMP, SMA, dan SMK yang menjadi sampel kajian. Guru tidak mengikuti FGD tetapi mengisi kuesioner. Kuesioner selain diberikan kepada seluruh guru yang menjadi sampel, juga diberikan kepada kepala sekolah. Baik guru maupun kepala sekolah diberi waktu 2-3 hari untuk mengisi kuesioner. Seluruh data yang terkumpul diolah berdasarkan karakteristik datanya. Data $F G D$ merupakan data kualitatif yang berisi narasi yang kemudian dianalisis dengan melakukan kategorisasi, reduksi, dan deskripsi berdasarkan pada variabel

Tabel 2 Lokasi dan Responden Peserta FGD

\begin{tabular}{llcccc}
\hline & Lokasi & \multicolumn{4}{c}{ Sumber Data (orang) } \\
\cline { 3 - 6 } & & $\begin{array}{c}\text { Dinas } \\
\text { pendidikan }\end{array}$ & Pengawas & $\begin{array}{c}\text { Kepala } \\
\text { Sekolah }\end{array}$ & Guru \\
\hline 1. & Kab. Sleman, D.I. Yogyakarta & 4 & 4 & 12 & 24 \\
2. & Kota Bengkulu, Bengkulu & 3 & 2 & 12 & 24 \\
3. & Kota Kupang, NTT & 4 & 4 & 12 & 24 \\
4. & Kab. Gianyar, Bali & 4 & 4 & 12 & 24 \\
5. & Kota Pontianak, Kalbar & 4 & 3 & 12 & 24 \\
6. & Kab. Kutai Kartanegara, Kaltim & 4 & 4 & 12 & 24 \\
7. & Kab. Bangka Tengah, Babel & 4 & 4 & 12 & 24 \\
8. & Kota Batam, Riau & 4 & 4 & 12 & 24 \\
9. & Kota Malang, Jawa Timur & 4 & 4 & 12 & 24 \\
10. & Kab. Pangkajene, Sulsel & 3 & 4 & 12 & 24 \\
\hline & & 38 & 37 & 120 & 240 \\
\hline
\end{tabular}


penelitian, sedangkan data angket dianalisis dengan menggunakan deskripsi statistik, terutama untuk mencari persentase dari masingmasing jawaban responden.

\section{HASIL KAJIAN DAN PEMBAHASAN}

Sebagaimana dijelaskan di depan, bahwa penelitian ini akan mengidentifikasi lima aspek yang berkontribusi terhadap peran pemda dalam implementasi Kurikulum 2013. Oleh karena itu, hasil dan pembahasan dipilah ke dalam aspekaspek tersebut.

\section{Sosialisasi}

Dalam suatu pembaruan kurikulum, sosialisasi mengenai konsep dan rancangan kurikulum kepada seluruh pemangku kepentingan menjadi sangat penting. Seperti dikemukakan oleh Hariana (2015), bahwa sosialisasi kurikulum merupakan satu tahap pengenalan atau proses pembelajaran kepada guru, kepala sekolah, pengawas untuk mempelajari kurikulum yang akan diterapkan, sesuai dengan konsep, isi, dan materi kurikulum yang akan diterapkan. Sosialisasi kurikulum baru pada hakikatnya merupakan proses pembelajaran kepada tenaga pengajar untuk mempelajari kurikulum yang akan diterapkan sesuai dengan konsep pengembangan kurikulum yang dapat dijalankan seusuai dengan tujuan (Hariana, 2015). Sulistyani (2014) juga menunjukkan bahwa sosialisasi berpengaruh secara positif dan signifikan terhapap perencanaan proses pembelajaran karena ketika sosialisasi meningkat maka perencanaan dalam pembelajaran juga meningkat, dan ketika sosialisasi menurun maka perencanaan proses pembelajaran juga menurun.

Pada tahap awal implementasi Kurikulum 2013, secara tegas sosialisasi tidak dicantumkan sebagai kegiatan yang dilakukan secara formal karena i tidak dianggarkan dalam APBN. Namun, daerah tetap melakukan sosialisasi Kurikulum 2013 kepada kepala sekolah, guru, pengawas. Kepala sekolah dan guru merupakan dua unsur penting dalam pelaksanaan Kurikulum 2013. Mereka merupakan pelaku utama dalam penerapan kurikulum karena mereka yang menerapkan secara langsung untuk pembelajaran. Berdasarkan pada hasil angket kepala sekolah dan guru di 10 lokasi sampel dalam penelitian ini, dari 127 kepala sekolah yang menjadi responden dalam penelitian ini sebesar $89 \%$ sisanya belum pernah mengikuti sosialisasi. Tren yang sama juga terlihat pada guru, yaitu $84 \%$ guru pernah mengikuti sosialisasi dan sebesar $16 \%$ belum pernah mengikuti sosialisasi. Hal ini menunjukkan bahwa sosialisasi memang belum menjangkau seluruh kepala sekolah dan guru yang berkepentingan dalam pelaksanaan Kurikulum 2013.

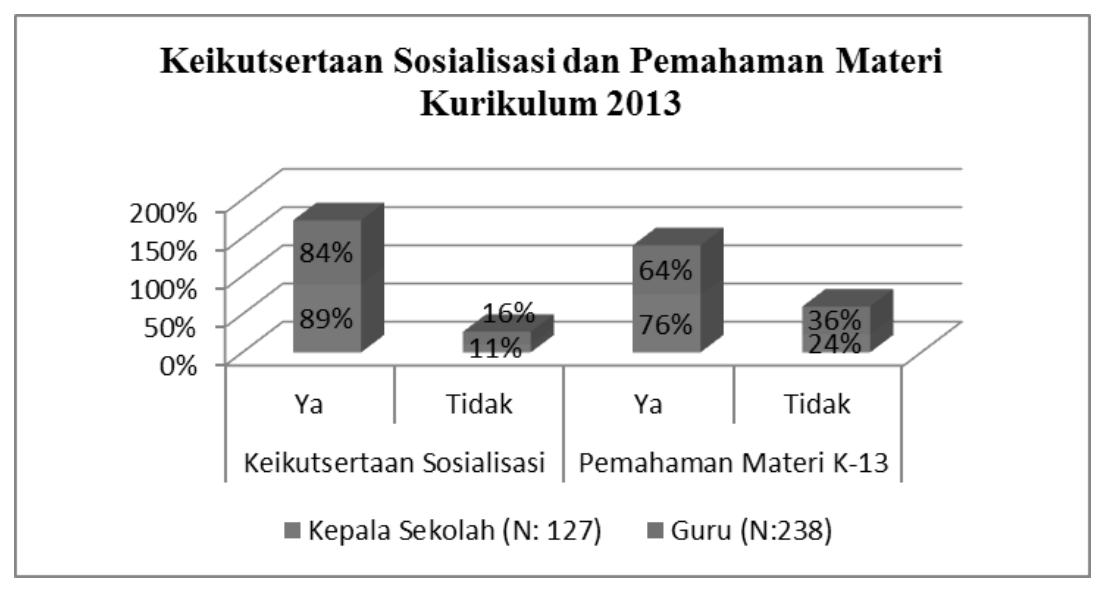

Gambar 1 Keikutsertaan Sosialisasi dan Pemahaman Materi Kurikulum 2013

Sumber: kuesioner (2014) 
Dalam hal pemahaman materi Kurikulum 2013 yang disampaikan melalui sosialisasi, sebagian besar kepala sekolah (76\%) dan guru (64\%) yang menyatakan sudah memahami pengenalan Kurikulum 2013 tahap awal tersebut dan sisanya sebesar $24 \%$ kepala sekolah dan guru $36 \%$ dari total responden menyatakan belum memahami kurikulum yang disosialisasikan tersebut. Dari $F G D$ terungkap bahwa ketidakpahaman para kepala sekolah dan guru ini mungkin dikarenakan materi yang disampaikan dalam sosialisasi masih bersifat umum dan mereka belum mendapatkan pelatihan. Di samping itu, peserta tidak selalu menjadi peserta pelatihan, karena keterbatasan kuota diklat. Sebagai contoh, salah seorang kepala sekolah SMK di Kota Bengkulu menyatakan banyak guru di sekolahnya masih bingung dalam melaksanakan Kurikulum 2013 walaupun sudah mengikuti sosialisasi.

Sosialisasi tidak dianggarkan sehingga tidak ada dana secara khusus. Biasanya sosialisasi Kurikulum 2013 dilakukan dengan berbagai cara, antara lain melalui rapat-rapat koordinasi ataupun bentuk kegiatan lain yang bukan merupakan kegiatan khusus sosialisasi kurikulum, sehingga materi yang diberikan hanya pengantar dan sangat umum. Kegiatan sosialisasi yang diselenggarakan daerah secara mandiripun mengundang narasumber dari pusat dan LPMP sehingga tidak terdapat perbedaan dalam materi sosialisasi yang disampaikan Setelah diklat biasanya masing-masing sekolah mengadakan pendalaman materi secara mandiri dengan mengundang narasumber dari LPMP.

Penyelenggaraan sosialisasi oleh dinas pendidikan kab/kota mendapat persentase terbesar kedua yaitu sebanyak $45 \%$ oleh responden kepala sekolah dan $27 \%$ oleh responden guru. Hasil ini memang sedikit kontradiktif jika dibandingkan dengan pernyataan yang terungkap dalam FGD karena masih ada daerah yang menyatakan tidak punya dana khusus untuk menyelenggarakan sosialisasi. Jika melihat dari respon kepala sekolah, guru serta pengawas yang menjadi sasaran sosialisasi, mereka menyatakan bahwa selama ini menerima undangan sosialisasi dari dinas pendidikan namun jika ditanya apakah dananya dari dinas pendidikan atau bukan, mereka menyatakan tidak tahu, sehingga dalam menjawab pertanyaan siapa yang mengadakan sosialisasi, sebagian besar menjawab dinas pendidikan kabupaten/kota karena undangan yang mereka terima diperoleh dari dinas pendidikan. Dari FGD juga terungkap bahwa secara umum sosialisasi yang diadakan di daerah bertujuan untuk menyiapkan guru-guru yang akan dipanggil untuk

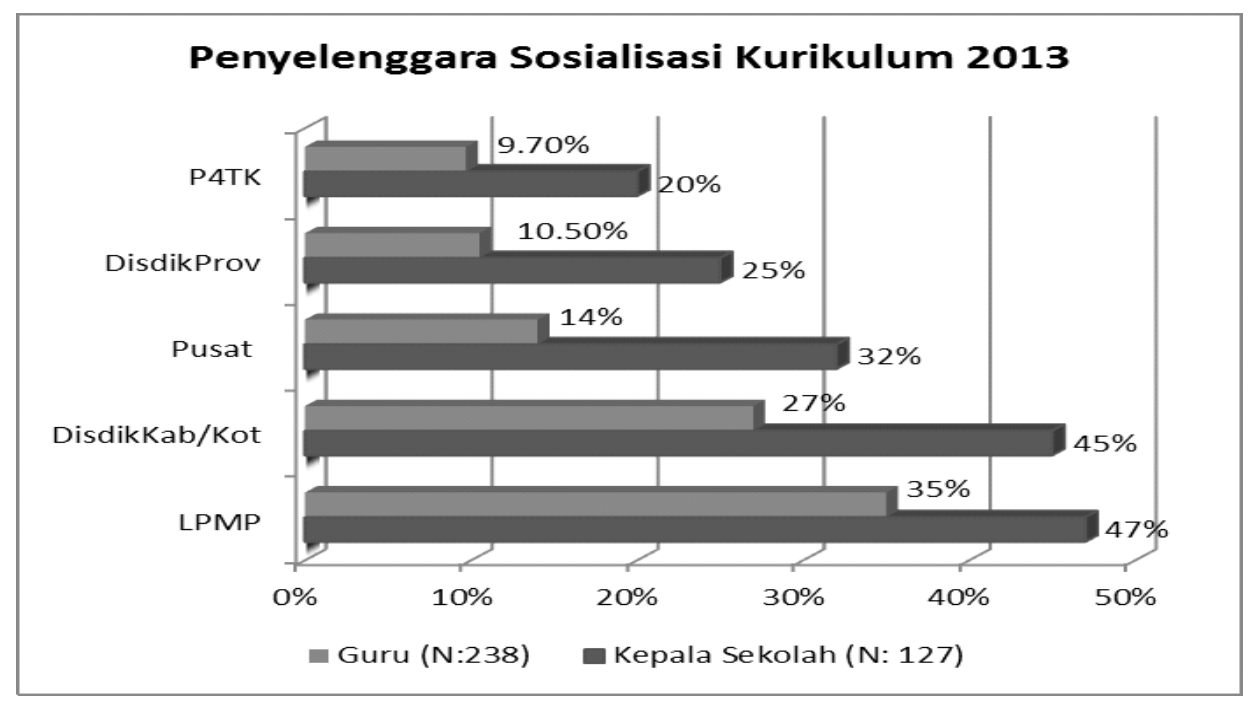

Gambar 2 Penyelenggara Sosialisasi Kurikulum 2013

Sumber: Kuesioner (2014) 
mengikuti pelatihan menjadi guru inti atau instruktur nasional, sehingga sekembalinya para guru inti dari pelatihan yang mereka ikuti, mereka menatar dan membina guru di daerahnya. Banyak sekolah yang juga melaksanakan sosialisasi dan pelatihan kurikulum dengan mengundang narasumber dari pemerintah pusat dan ataupun LPMP setempat. Terkait dengan sasaran atau peserta sosialisasi dan materi yang diberikan, tidak terdapat perbedaan antara daerah yang melakukan sosialisasi secara mandiri dengan dana APBD (selain mengikuti sosialisasi yang diselenggarakan oleh pemerintah pusat) dengan daerah yang tidak mempunyai dana khusus. Sasaran sosialisasi Kurikulum 2013 ini adalah kepala sekolah, guru dan pengawas, dan selanjutnya pendalaman materi dilakukan pada saat pendidikan dan pelatihan Kurikulum 2013 dilakukan.

Dari uraian tersebut di atas dapat disimpulkan bahwa walaupun secara formal sosialisai Kurikulum 2013 tidak dianggarkan namun berbagai pihak memandang perlu melakukan sosialisasi. LPMP merupakan pihak yang paling aktif melakukan sosialisasi. Hal ini bisa dimengerti karena Lembaga Penjamin Mutu Pendidikan (LPMP), berdasarkan Permendikmas Nomor 66 tahun 2008, mempunyai tugas dan fungsi untuk memfasilitasi peningkatan kompetensi dan profesionalisme pendidik dan tenaga kependidikan sehingga kegiatan sosialisasi merupakan salah satu fasilitasi yang dilakukan oleh LPMP. Di samping LPMP, dinas pendidikan kabupaten/kota juga cukup aktif melakukan sosialisasi. Namun, walaupun sudah mengikuti sosialisasi, sepertiga dari sampel kepala sekolah dan guru belum memahami Kurikulum (Lihat Gambar 1). Hal ini menunjukkan sosialisasi belum efektif. Hariana (2015), dalam kajiannya mengenai penerapan Kurikulum 2013 juga menemukan bahwa sosialisasi yang diberikan kepada guru-guru belum efektif dan sangat tergesa-gesa karena sosialisasi hanya diadakan sekali yaitu pada bulan Maret dan Juli 2013, beberapa bulan sebelum impelementasi.

\section{Pelatihan Guru, Kepala Sekolah, dan Pengawas}

Kurikulum 2013 mensyaratkan guru berperan secara maksimal dalam pembelajaran. Oleh karena itu, diperlukan pelatihan khusus yang harus diberikan kepada guru dan kepala sekolah. Pada saat penelitian dilakukan, yaitu sekitar bulan September dan Oktober 2014, belum seluruh responden guru dan responden kepala sekolah mengikuti pelatihan Kurikulum 2013. Pada Gambar 3 menunjukkan bahwa dari 127 orang kepala sekolah $86 \%$ yang sudah mengikuti pelatihan Kurikulum 2013 dan dari 238 guru yang menjawab angket $81 \%$ yang telah mengikuti pelatihan Kurikulum 2013. Jadi, masih ada 14 persen kepala sekolah dan 19 persen guru yang belum mengikuti pelatihan Kurikulum 2013. Sementara itu, implementasi Kurikulum 2013 sudah memasuki tahun ke dua dan semester pertama sudah berjalan. Hal ini menunjukkan bahwa ada kepala sekolah atau guru yang belum mendapatkan pengetahuan secara formal mengenai Kurikulum 2013 tetapi sudah harus melaksanakan di sekolah atau di kelas. Disyaratkan bahwa guru atau kepala sekolah harus mengikuti pelatihan Kurikulum 2013 paling tidak 58 jam untuk bisa mengerti dan memahami Kurikulum 2013. Bagi kepala sekolah, pelatihan Kurikulum 2013 merupakan hal yang sangat penting. Dengan demikian, semestinya seluruh kepala sekolah dilatih Kurikulum 2013 karena ia adalah sebagai pimpinan dan manajer serta pengajar yang berkewajiban memberikan sosialisasi, motivasi, membimbing dan mengevaluasi seluruh kegiatan sekolah, khususnya dalam rangka implemantasi Kurikulum 2013. Selain itu, iapun wajib memperoleh pelatihan untuk menguasai materi Kurikulum 2013. Kepala sekolah yang belum mendapatkan pelatihan Kurikulum 2013 ini merupakan kepala sekolah yang berasal dari sekolah terpencil, sekolah swasta, atau memang belum terdaftar sebagai peserta pelatihan. Terlepas dari masalah tersebut, banyaknya kepala sekolah yang telah dilatih Kurikulum 2013 tersebut menunjukkan 
bahwa telah ada peran yang positif dari pemerintah daerah (dinas pendidikan) dalam pelatihan Kurikulum 2013.

Berdasarkan data yang ada, pemahaman guru terhadap materi Kurikulum 2013 yang diperoleh dari pelatihan ternyata belum memuaskan semua guru. Masih ada 39,6\% guru merasa belum memahami materi Kurikulum 2013, sedangkan 60,4\% merasa telah memahami Kurikulum 2013. Bagian-bagian Kurikulum 2013 yang semestinya dipahami antara lain mencakup aspek rasional dan elemen perubahan Kurikulum 2013, strategi implementasi Kurikulum 2013, pendekatan pembelajaran dan penilaian pada Kurikulum 2013, isi buku dan cara menganalisisnya. Hasil FGD di banyak lokasi memberikan informasi bahwa komponen yang paling sulit dalam Kurikulum 2013 yaitu dalam melaksanakan pengembangan model pembelajaran yitu Project Based Learning, Problem Based Learning/ Discovery Learning/Inquiry Learning, dan cara penilaian pembelajaran yang sifatnya portofolio dan kualitatif. Dalam pelatihan, komponen tersebut belum dilatih secara mendalam dan belum cukup memberikan contoh-contoh melalui praktek nyata dalam pembelajaran sehingga terjadi ketidakjelasan dalam melakukan penilaian. Demikian pula contoh berupa format penilaian juga dirasa belum diberikan secara nyata dan komprehensif sehingga para guru masih belum memahami dan sulit mempraktikkannya dalam penilaian individual secara deskriptif kualitatif. Dengan demikian, guru belum mempunyai kemampuan yang memadai untuk melakukan penilaian hasil belajar siswa.

Penyelenggara pelatihan Kurikulum 2013 bagi kepala sekolah diselenggarakan oleh beberapa pihak, yaitu pemerintah pusat (Kemdiknas) dan UPT (LPMP dan P4TK) serta oleh pemda (dinas pendidikan provinsi dan dinas pendidikan kabupaten/kota). Pihak-pihak penyelenggara pelatihan Kurikulum 2013 untuk guru dan kepala sekolah ini juga mengindikasikan peran daerah dalam pelatihan Kurikulum 2013. Gambar 3 menunjukkan bahwa penyelenggara pelatihan Kurikulum 2013 untuk guru sebagian besar diselenggarakan oleh pemerintah pusat baik secara langsung maupun melalui UPT di daerah. Ini terlihat dari pernyataan kepala sekolah yang mengemukakan bahwa pelatihan Kurikulum 2013 yang diselenggarakan oleh pusat sebesar 9,2\%, oleh P4TK sebesar 15,5\%, dan oleh LPMP sebesar $56,7 \%$. Hanya sebesar $16 \%$ guru yang menyatakan mengikuti diklat yang diselenggarakan oleh pemerintah daerah. Hal ini menunjukkan bahwa secara umum pemerintah daerah tidak/belum terlibat secara penuh dalam pelatihan Kurikulum 2013 pada guru. Sementara itu, pada tingkat pelatihan kepala sekolah juga menunjukkan kecenderungan yang sama, yaitu penyelenggara pelatihan Kurikulum 2013 bagi kepala sekolah didominasi dari pemerintah pusat. Para kepala sekolah

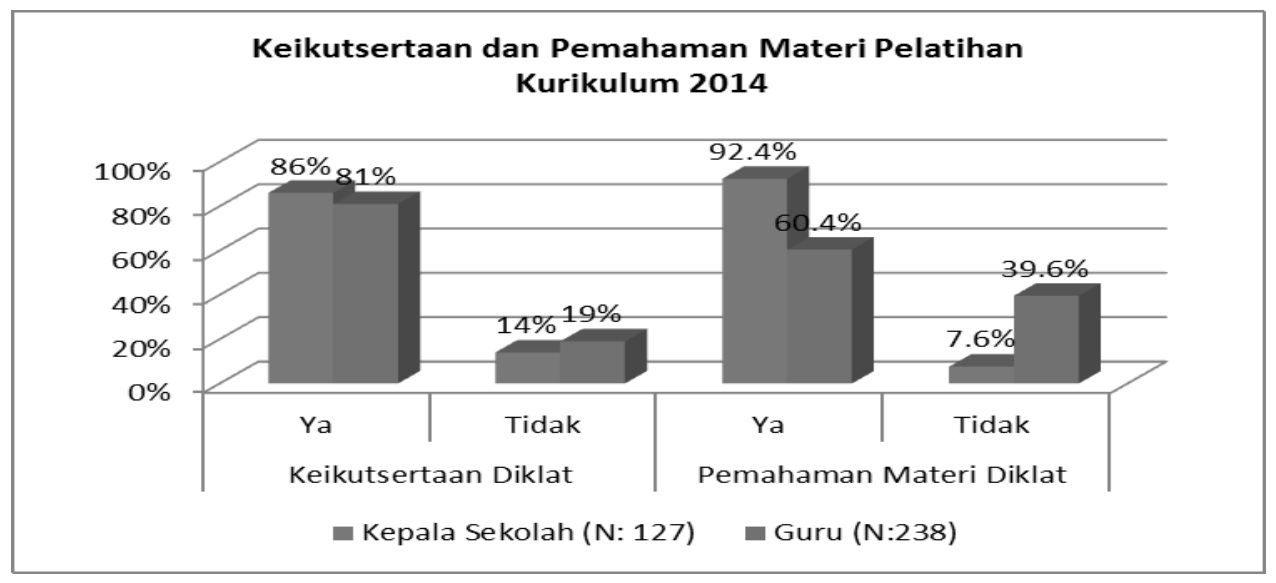

Gambar 3 Keikutsertaan dalam Pelatihan dan Penyelenggara Pelatihan 
memberikan informasi bahwa pemerintah pusat baik secara langsung maupun melalui UPT, pelatihan Kurikulum 2013 yang diselenggarakan oleh pusat sebesar 24\%, oleh P4TK sebesar $28 \%$ dan LPMP $47 \%$; sedangkan kepala sekolah yang mengikuti pelatihan yang diselenggarakan oleh pemerintah daerah ada sebesar $22 \%$. Dengan demikian, terlihat bahwa pelatihan untuk guru dan kepala sekolah lebih banyak diselenggarakan oleh pemerintah pusat.

Dari uraian tersebut di atas, dapat disimpulkan walaupun pelatihan telah diberikan, belum seluruh guru mengikuti pelatihan. Pada saat kajian ini mulai dilakukan pada Agustus 2014, dari target pemerintah untuk melatih 1,3 juta guru secara bertahap, baru 283.000 guru yang sudah dilatih (Alawiyah, 2014)). Selanjutnya, menurut Alawiyah (2014), walaupun guru yang telah mengikuti pelatihan Kurikulum 2013 mengalami perubahan dalam mengajar, seperti guru menjadi lebih aktif, kreatif dan menyenangkan, namun masih banyak guru yang setelah pelatihan pun belum memahami dalam mengimplementasikan kurikulum. Hal ini mungkin disebabkan waktu pelatihan yang terlalu singkat, metode pelatihan yang kurang tepat, atau kompetensi instruktur yang kurang. Kajian Budi (2014) juga menunjukkan bahwa walaupun guru telah mendapatkan in-house training, yaitu pelatihan kurikulum yang diadakakan di sekolah, guru masih mengalami kebingungan dalam menerapkan Kruikulum 2013, terumata dalam menerapkan metode mengajar dan sistem penilainnya.

\section{Pengadaan dan Distribusi Buku Kurikulum 2013}

Pengadaan/pembelian buku teks Kurikulum 2013 (buku siswa dan panduan guru) diatur dalam Permendikbud Nomor 34 Tahun 2014 bahwa sekolah menyampaikan Surat Pemesanan buku Kurikulum 2013 mulai tanggal 3 Mei 2014 dan paling lambat 28 Mei 2014 kepada penyedia buku melalui dinas pendidikan kabupaten/kota. Sekolah tidak diperkenankan membeli buku K13 selain buku yang disediakan oleh pihak penyedia buku yang menjadi pemenang lelang yang ditetapkan Lembaga Kebijakan Pengadaan Barang/Jasa Pemerintah (LKPP). Karena itu, mekanisme pengadaan buku diatur oleh pemerintah pusat bekerja sama dengan LKPP. LKPP ini berfungsi untuk menetapkan harga buku, biaya pengiriman ke sekolah, menetapkan spesifikasi buku, mengatur kontrak antara sekolah dengan penyedia buku, menerbitkan ekatalog, dan menyiapkan pembayaran epurchasing. Pada awal bulan Mei 2014 LKPP telah menetapkan 31 penyedia/penerbit/ percetakan yang telah memenangkan lelang pengadaan buku, karena itu antara bulan MeiJuli waktu bagi penerbit untuk proses cetak dan distribusi buku Kurikulum 2013 hingga ke sekolah, sehingga pada bulan Juli buku sudah diterima di sekolah. Namun, perencanaan waktu yang dilakukan oleh pemerintah pusat tersebut tidak terpenuhi, sehingga ketika proses pembelajaran semester 1 tahun 2014 dimulai buku belum sampai ke sekolah, bahkan hingga Oktober 2014

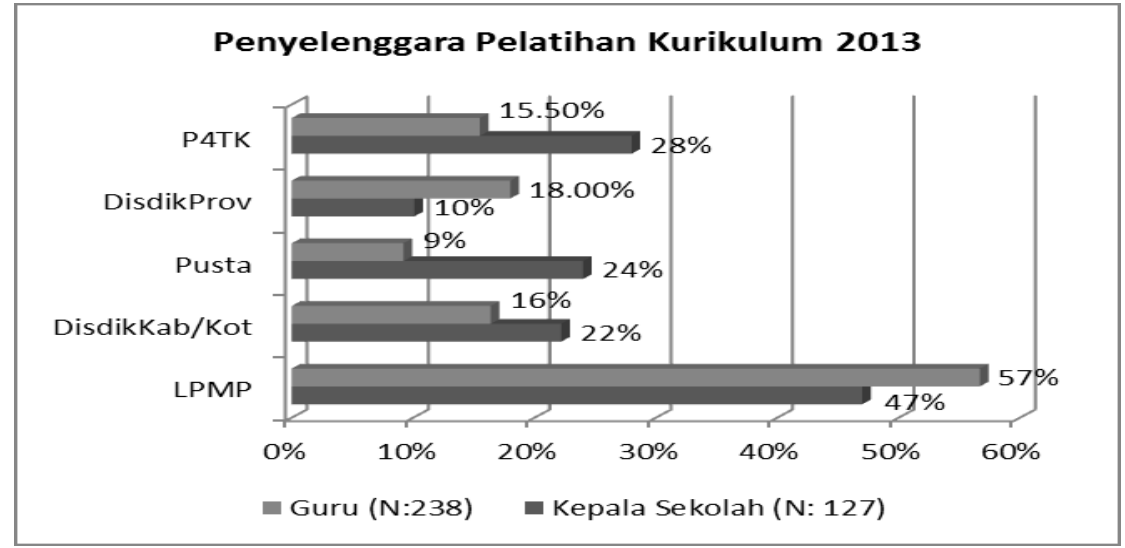

Gambar 4 Penyelenggara Pelatihan Kurikulum 2013 
ketika penelitian ini dilakukan banyak sekolah maupun daerah yang belum menerima buku, baik buku siswa maupun buku panduan guru.

Dari FGD, para kepala sekolah menyampaikan bahwa telah melakukan pemesanan buku melalui dinas pendidikan kabupaten/kota secara online lewat e-katalog sesuai jadwal dan prosedur pemesanan, yaitu buku siswa dipesan sesuai dengan jumlah siswa dan buku panduan guru sesuai dengan jumlah guru (guru kelas atau guru mata pelajaran) serta serta buku cadangan di perpustakaan ( $5 \%$ untuk SD dan $10 \%$ untuk SMA/SMK). Tabel 3 menunjukkan rata-rata jumlah buku yang dipesan oleh sekolah secara keseluruhan. Pada tingkat SD rata-rata sekolah memesan buku siswa 1096 eksemplar buku teks pelajaran bagi siswa SD dan 47 eksemplar buku panduan guru. Pada tingkat SMP rata-rata memesan 2172 eksemplar bteks pelajaran bagi siswa SMP dan 60 eksemplar buku panduan guru. Pada tingkat SMA/SMAK rata-rata memesan 4262 eksemplar buku teks peserta didik, dan 67 eksemplar buku panduan guru.

Pada awal tahun pelajaran 2014/2015 sekolah umumnya sudah memesan buku teks pelajaran bagi siswa maupun buku panduan guru sesuai dengan kebutuhan. Namun, hingga bulan September 2014 sekolah belum menerima buku teks pelajaran bagi siswa dan buku panduan guru, sehingga selama 3 bulan buku yang dipesan belum sampai ke sekolah. Belum sampainya buku ke sekolah membuat sekolah berusaha dengan berbagai cara. Dengan bantuan dinas pendidikan kabupaten/kota, sekolah menggandakan sampel buku maupun $C D$ yang dikirim dari pusat. Hal ini juga terungkap dari FGD kepala sekolah yang menyatakan bahwa sekolah berusaha memenuhi kebutuhan buku teks siswa dan buku panduan guru dengan membuat foto kopi buku-buku tersebut, serta menggandadkan $C D$ buku teks pelajaran siswa dan buku panduan guru. Namun hal ini berdampak pada bertambah besarnya pengeluaran siswa/orangtua karena biaya foto kopi lebih mahal daripada harga asli buku-buku tersebut. Walaupun orangtua sebenarnya keberatan untuk mengeluarkan biaya tambahan, anak membutuhkan buku untuk kegiatan belajarnya, dan sekolah tidak mampu menyediakan foto kopi buku untuk seluruh siswa, sehingga sekolah melibatkan orangtua untuk memenuhi kebutuhan buku tersebut. Keterlibatan sekolah dalam pengadaan buku yang dipersyaratkan bagi pelaksanaan Kurikulum 2013 sudah dimulai dari awal dalam perencanaan kebutuhan buku. Gambar 4 menunjukkan keterlibatan sekolah dalam pengadaan buku untuk pelaksanaan Kurikulum 2013. Hampir seluruh sekolah melakukan koordinasi dengan dinas pendidikan dan lembaga terkait untuk memenuhi kebutuhan buku $(99,1 \%)$ dan dalam pengadaannya $(90,8 \%)$. Dalam hal pendanaan untuk pengadaan buku, sebesar $94 \%$ sekolah memenuhi pengadaan buku dari dana BOS, dan $71 \%$ menyatakan mengandalkan dana dari pemerintah pusat, dan sebesar $40 \%$ menyatakan bahwa pengadaan buku berasal dari dana daerah.

Tabel 3 Rata-rata Jumlah Buku yang dipesan oleh sekolah

\begin{tabular}{llrr}
\hline No & \multicolumn{1}{c}{ Jenis buku } & N & Rata-rata \\
\hline 1 & Jumlah buku siswa SD & 22 & 1096 \\
2 & Jumlah buku guru SD & 20 & 47 \\
3 & Jumlah buku siswa SMP & 14 & 2172 \\
4 & Jumlah buku guru SMP & 9 & 60 \\
5 & Jumlah buku siswa SMA/K & 29 & 4262 \\
6 & Jumlah buku guru SMA/K & 27 & 67 \\
\hline
\end{tabular}

Sumber: Kuesioner (2014). 


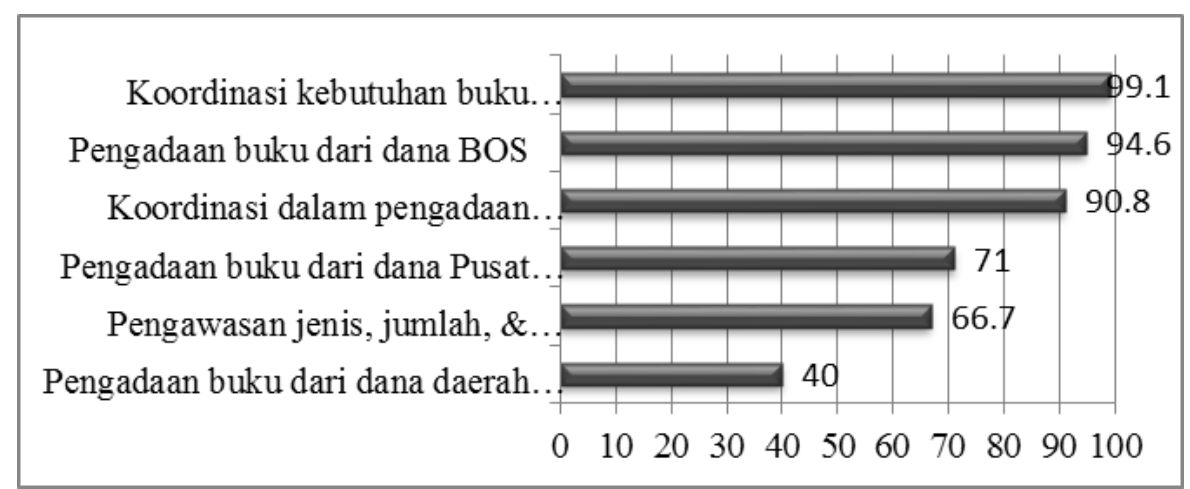

Gambar 4 Keterlibatan Sekolah dalam Pengadaan Buku

Sumber: Kuesioner (2014)

Walaupun pengadaan buku teks pelajaran Kurikulum 2013 berada di tingkat pusat, daerah juga berperan. Peran tersebut adalah menyiapkan anggaran penggandaan dan pendistribusian buku teks pelajaran bagi siswa maupun buku panduan guru untuk semester 2 tahun ajaran 2014/2015 sampai ke sekolah untuk seluruh kelas, yaitu kelas I, II, IV, V, VII, VIII, X, dan XI bagi pemerintah daerah kabupaten/kota yang tidak mendapatkan DAK bidang pendidikan. Selain itu, untuk semester 2 tahun 2014 pemerintah daerah bisa lebih berperan untuk lebih menuntaskan pendistribusian buku. Sebagai contoh sampai pertengahan bulan September 2014 pengadaan dan distribusi buku teks pelajaran bagi siswa maupun buku panduan guru telah berjalan baik, yaitu di tingkat SD 100\% sekolah telah menerima buku, di tingkat SMP seluruh sekolah belum menerima buku, dan di tingkat SMA dan SMK sebesar 37\% sekolah telah menerima buku (lihat Tabel 4).

Distribusi buku Kurikulum 2013 merupakan permasalahan tersendiri. Distribusi buku Kurikulum 2013 ini menjadi tanggung jawab penyedia/penerbit buku. Distribusi yang dimaksud dalam konteks ini merupakan proses pengiriman buku teks siswa dan buku pedoman guru untuk melaksanakan pembelajaran dengan Kurikulum 2013 sampai ke seluruh sekolah di kabupaten/kota. Tabel 4 menyajikan temuan di 10 kabupaten/kota bahwa hingga pertengahan semester pertama (sekitar bulan September) tahun 2014. Secara umum sekolah belum menerima buku teks pelajaran, baik buku siswa maupun buku panduan guru. Kabupaten Sleman (buku SD semua sekolah sudah memperoleh buku siswa), dan Kota Malang (buku siswa SD, SMP, SMA, dan SMK semua sekolah telah menerima buku siswa). Sedangkan untuk buku panduan guru, belum satupun daerah yang memperolehnya. Kabupaten Kutai Kartanegara, dan Kota Kupang, untuk seluruh siswa dan seluruh guru untuk semua jenjang sekolah, belum mendapat buku teks pelajaran, baik buku siswa maupun buku panduan guru. Sedangkan di Kabupaten Pangkajene kondisinya relatif lebih baik yaitu seluruh sekolah pada tingkat SMA dan SMK sudah menerima buka siswa, di tingkat SMP 65\% dan di tingkat SD 25\%. Namun, buku guru untuk semua jenjang belum menerima sama sekali. Hal tersebut menunjukkan kondisi yang bervariasi, yang menurut pihak sekolah hal ini dipengaruhi oleh intensifnya dinas pendidikan maupun sekolah untuk selalu memonitor perkembangan pengadaan buku di pusat. Data harian Kompas, Tanggal 13 Desember 2014 menunjukkan bahwa dari 6.221 sekolah yang sudah menerapkan Kurikulum 2013 sejak Juli 2013, baru 67\% untuk SD, 83\% untuk SMP yang telah menerima buku pada semester 1.

Menghadapi ketiadaan buku, pada umumnya sekolah yang belum memiliki buku Kurikulum 2013 untuk pembelajaran pada semester 1 tahun pelajaran 2014/2015 memanfaatkan CD yang 
Tabel 4 Ketersediaan Buku Kurikulum 2013 untuk Semester 1 Tahun 2014/2015

\begin{tabular}{clrrrrrrrr}
\hline & & \multicolumn{4}{c}{ Buku Siswa } & \multicolumn{4}{c}{ Buku Guru } \\
\cline { 2 - 9 } No & \multicolumn{1}{c}{ Kab/Kota } & SD & SMP & SMA & SMK & SD & SMP & SMA & SMK \\
\hline 1 & Kab. Kutai Kartanegara & $0 \%$ & $0 \%$ & $0 \%$ & $0 \%$ & $0 \%$ & $0 \%$ & $0 \%$ & $0 \%$ \\
2 & Kota Kupang & $0 \%$ & $0 \%$ & $0 \%$ & $0 \%$ & $0 \%$ & $0 \%$ & $0 \%$ & $0 \%$ \\
3 & Kab. Gianyar & $0 \%$ & $100 \%$ & $90 \%$ & $90 \%$ & $0 \%$ & $0 \%$ & $0 \%$ & $0 \%$ \\
4 & Kab. Sleman & $100 \%$ & $0 \%$ & $37 \%$ & $37 \%$ & $0 \%$ & $0 \%$ & $0 \%$ & $0 \%$ \\
5 & Kota Bengkulu & $50 \%$ & $20 \%$ & $20 \%$ & $20 \%$ & $0 \%$ & $0 \%$ & $0 \%$ & $0 \%$ \\
6 & Kota Malang & $100 \%$ & $100 \%$ & $100 \%$ & $100 \%$ & $0 \%$ & $0 \%$ & $0 \%$ & $0 \%$ \\
7 & Kota Batam & $0 \%$ & $0 \%$ & $0 \%$ & $0 \%$ & $0 \%$ & $0 \%$ & $0 \%$ & $0 \%$ \\
8 & Kota Pontianak & $0 \%$ & $0 \%$ & $0 \%$ & $0 \%$ & $0 \%$ & $0 \%$ & $0 \%$ & $0 \%$ \\
9 & Kab. Bangka Tengah & $0 \%$ & $0 \%$ & $0 \%$ & $0 \%$ & $0 \%$ & $0 \%$ & $0 \%$ & $0 \%$ \\
10 & Kab. Pangkajene & $25 \%$ & $65 \%$ & $100 \%$ & $100 \%$ & $0 \%$ & $0 \%$ & $0 \%$ & $0 \%$ \\
\hline
\end{tabular}

Sumber: Data diolah dari kuesioner (2014)

berisi perangkat buku teks pelajaran bagi siswa dan buku panduan guru atau memotokopi dari buku yang ada. Penggandaan $C D$ atau fotokopi buku merupakan kebijakan daerah yang bekerja sama dengan sekolah untuk menjamin proses kegiatan belajar mengajar tetap berlangsung. Penggandaan $C D$ atau melalui fotokopi biasanya dilakukan sesuai dengan bagian atau tema yang sedang dibutuhkan dalam kegiatan pembelajaran. Pada saat itu sekolah tidak menggandakan seluruh isi buku untuk menghindari anggaran yang besar. Di samping itu, pihak dinas pendidikan umumnya juga memberi instruksi agar pendanaan untuk penggandaan buku dialokasikan dari dana BOS atau dana Bansos. Sekolah memasukkannya dalam anggaran sekolah yang bersumber dari dana BOS terkait, dan menyarankan agar sekolah juga memberikan keleluasaan kepada para orangtua siswa jika mereka menginginkan fotokopi materi buku tersebut dengan biaya sendiri. Dinas pendidikan di daerah secara intensif berkoordinasi dan mendatangi pihak penerbit untuk mengetahui posisi pesanan bukunya, seperti yang dilakukan Dinas Pendidikan Kabupaten Pangkajene dan Kota Pontianak. Data FGD menunjukkan bahwa kapasitas percetakan buku yang terbatas mengakibatkan keterlambatan dalam penyediaan, yang kemudian menyebabkan keterlambatan distribusi. Berdasarkan pada kajian
Simamora (2014) mengenai manajemen dan penulisan buku teks pelajaran Kurikulum 2013 menunjukkan bahwa manajemen penerbitan juga mempengaruhi ketepatan ketersediaan buku. Manajemen penerbitan buku terkait dengan perekrutan editor, illustrator, tataletak, dan desainer. Oleh karena itu, alur naskah harus memberi perhatian khusus untuk menghindari koreksi naskah yang berkali-kali.

\section{Pendanaan Pelakasanaan Kurikulum 2013}

Peran pemerintah daerah dalam pendanaan pelaksanaan Kurikulum 2013 sangat bervariasai. Pada tahun pertama pelaksanaan Kurikulum 2013, tidak ada peran emerintah daerah dalam pendanaan karena dana pelaksanaan K-13 seluruhnya berasal dari dana pusat (APBN). Walaupun pemda belum menganggarkan dana untuk pelaksanaan Kurikulum 2013, daerah mendukung pelaksanaan Kurikulum 2013. Sebagai contoh, Pemda Kota Malang mendukung pelaksanaan Kurikulum 2013 di seluruh sekolah di Kota Malang, yang pendanaannya ditanggung secara mandiri oleh sekolah. 19 sekolah yang menjadi pilot project saja yang mendapatkan dana. Namun, seluruh sekolah di Kota Malang melaksanakannya dengan pendanaan secara mandiri karena pada tahun pertama Pemda Kota Malang belum menganggarkan dana untuk itu. Apa yang dilakukan Pemda Kota Malang 
menunjukkan bahwa respon sekolah cukup besar untuk melaksanakan Kurikulum 2013. FGD dengan kepala sekolah terungkap alasan mengapa seluruh sekolah ingin melaksanakan Kurikulum 2013 secara mandiri karena sekolahsekolah tersebut tidak ingin tertinggal dengan sekolah lain dalam pengembangan kurikulum. Menurut salah satu aparatur dinas pendidikan, sekolah ingin melaksanakan Kurikulum 2013 secara mandiri karena bila memulainya berbeda dengan sekolah lain (sekolah pilot project) dan seandainya menghadapi masalah dalam pelaksanaan nantinya akan kesulitan untuk memecahkannya karena sekolah lain telah lebih dulu melaksanakan.

Pendanaan dalam implementasi Kurikulum 2013 bisa dilihat dari pendanaan pada tingkat pemda yang dilakukan melalui dinas pendidikan kabupaten/kota dan pendanaan di tingkat sekolah yang dilaksanakan oleh sekolah/kepala sekolah dalam melaksanakan pembelajaran dengan Kurikulum 2013. Dalam skema pembiayaan implementasi Kurikulum 2013, pelaksanaan tahun 2013 seluruh pembiayaan di tanggung oleh pemerintah pusat, sedang di tahun kedua pembiayaan implementasi Kurikulum 2013 akan bersumber dari DAK dan dana BOS. Namun dalam pelaksanaannya, dinamika di daerah memberikan kondisi yang berbeda. Tahun pertama pelaksanaan Kurikulum 2013, walaupun pemerintah pusat hanya mendanai sekolah yang terpilih sebagai sampel (pilot project), ada banyak daerah yang kemudian berinisiatif untuk menambah jumlah sekolah yang mengimplementasikan Kurikulum 2013. Bahkan, ada daerah yang telah menerapkan Kurikulum 2013 di seluruh sekolah. Hal ini tentu saja akan berimplikasi pada pendanaan. Partisipasi pemerintah daerah dalam implementasi Kurikulum 2013 ditunjukkan dengan penyediaan dana APBD dalam pelaksanaan Kurikulum 2013. Tabel 5 menunjukkan besarnya alokasi dana yang dikeluarkan oleh pemerintah daerah dalam pelaksanaan Kurikulum 2013 di daerahnya.

Pada tahun 2014, 10 kabupaten/kota yang menjadi sampel dalam studi ini telah ikut berpartisipasi dan terlibat dalam pendanaan untuk melaksanakan Kurikulum 2013, yaitu berupa penyediaan dana APBD untuk pelaksanaan Kurikulum 2013. Ada lima daerah yang secara khusus telah menyediakan dana untuk mengadakan pelatihan bagi guru, kepala sekolah dan pengawas, dengan jumlah sasaran dan jumlah dana yang secara jelas disediakan. Sebagai contoh, Kabupaten Kutai Kartanegara telah menyediakan dana sebesar 1,13 milyar untuk membiayai diklat guru dan kepala sekolah di seluruh Kabupaten Kutai Kartanegara. Dengan demikian ketika penelitian ini dilakukan seluruh guru dan kepala sekolah pernah mengikuti pelatihan Kurikulum 2013. Pemda Kota Malang juga menyediakan dana APBD yang memang digunakan untuk diklat seluruh guru. Pada saat penelitian ini dilakukan seluruh sekolah dari SD, SMP, dan SMA, baik swasta maupun negeri di Kota Malang telah melaksanakan Kurikulum 2013. Bahkan sejak tahun 2013 seluruh sekolah juga sudah ikut melaksanakan Kurikulum 2013 dengan biaya sekolah sendiri.

Pemda Kota Kupang, Kabupaten Gianyar, dan Kabupaten Sleman juga telah mengalokasikan dana APBD untuk pendidikan dan pelatihan guru, kepala sekolah, dan pengawas walaupun belum seluruh guru/kepala sekolah/ pengawas mendapatkan kesempatan untuk mengikutinya. Pemda Kabupaten Bangka Tengah dan Kabupaten Pangkajene Kepulauan juga telah mengalokasikan dana untuk pelatihan guru walaupun belum menyasar seluruh guru/kepala sekolah/pengawas di daerah tersebut. Pemda tersebut tidak menyebut jumlah dana secara pasti tetapi hanya menetapkan target jumlah guru yang akan menjadi sasaran pelatihan. Kota Bengkulu, Kota Batam, dan Kota Pontianak secara eksplisit belum menganggarkan dari dana APBD. Walaupun demikian, mereka memberikan berbagai variasi dukungan dalam pelaksanaan Kurikulum 2013. Misalnya, memberikan fasilitas sarana atau prasarana yang diperlukan, memberikan dukungan dalam pelatihan-pelatihan yang diadakan baik oleh LPMP, P4TK maupun provinsi. 
Tabel 5 Anggaran APBD untuk Implementasi Kurikulum 2013 di Tingkat Kabupaten/Kota

\begin{tabular}{clll}
\hline No & Kabupaten/Kota & Alokasi (Rp) & Penggunaan \\
\hline 1. & Kab. Kutai Kartanegara & 1,13 Milyar & Bimtek \& pelatihan \\
2. & Kota Kupang & 500 juta & Sosialisasi, pelatihan, pendampingan \\
3. & Kab. Gianyar & 970 juta & Pelatihan bagi 1.800 guru \\
4. & Kab. Sleman & 700 Juta & Pelatihan 1.800 guru \\
5. & Kota Bengkulu & Rencana & Pelatihan 1500 guru di SMT 2 \\
6. & Kota Malang & $2.5 \mathrm{M}$ & Pelatihan semua guru \\
7. & Kota Batam & Var. dukungan & MGMP, bantuan dari penerbit \\
8. & Kota Pontianak & n.a & Pelatihan guru \\
9. & Kab. Bangka Tengah & $2 \mathrm{M}$ & Pelatihan guru 24 SD dari 29 SD \\
10. & Kab. Pangkajene & & Pelatihan 400 guru \\
\hline
\end{tabular}

Sumber: Data diolah dari kuesioner dan FGD (2014)

Berdasarkan hasil FGD dari daerah sampel yang telah dilakukan, terungkap bahwa hanya sebagian dinas pendidikan kabupaten/kota yang secara khusus menganggarkan dana untuk kegiatan sosialisasi. Dari 10 kabupaten/kota yang diteliti, 5 daerah mengungkapkan bahwa terdapat dana khusus untuk kegiatan sosialisasi di daerahnya yaitu Kabupaten Gianyar, Pangkajene Kepulauan, Kutai Kartanegara, Kupang dan Batam. Sedangkan, 5 daerah lainnya menyebutkan tidak secara khusus menganggarkan dana karena segala bentuk pendampingan dirasa sudah cukup dilaksanakan oleh pemerintah pusat dan LPMP.

Dapat disimpulkan bahwa peran atau kontribusi pemerintah daerah dalam pendanaan yang bersumber dari dana APBD cukup bervariasi. Bila dilihat dari indeks kapasitas fiskal daerah sampel, daerah dengan indeks kapasitas fiskal tinggi cenderung untuk mengalokasi dana relatif tinggi bagi pelatihan guru dan kepala sekolah, seperti Kabupaten Kutai kartanegara dan Kabupaten Bangka Tengah. Namun, daerah dengan indeks kapasitas fiskal yang sedang atau rendah, seperti Kota Malang, Kabupaten Gianyar, atau Kabupaten Sleman juga mengalokasikan cukup dana dari APBD. Dukungan dalam bentuk pendanaan tersebut dipengaruhi oleh komitmen daerah maupun sekolah yang cukup tinggi untuk secara bersama mengimplementasikan kurikulum.

\section{Monitoring Dan Evaluasi (Monev)}

Dinas pendidikan mempunyai wewenang untuk melakukan monitoring dan evaluasi terhadap seluruh sekolah di wilayah kabupaten/kota. Namun dinas pendidikan kabupaten/kota pun dimonitor oleh instansi yang lebih tinggi, yaitu dinas provinsi dan Kemendikbud, dan pihak lain. Pada saat kajian ini dilakukan, secara umum monitoring dan evaluasi sudah berjalan tetapi belum secara intensif dilakukan karena baik di tingkat pemerintah daerah maupun di tingkat sekolah masih menghadapi permasalah lain, seperti pelatihan guru, distribusi guru, dan pendanaan. Meskipun belum intensif dilaksanakan, monitoring dan evaluasi sudah dilakukan baik di tingkat dinas pendidikan maupun di tingkat sekolah.

Berdasarkan pernyataan kepala sekolah, monitoring di tingkat sekolah telah dilakukan oleh ketiga instansi tersebut di atas. Instansi yang paling sering melakukan monitoring di sekolah adalah dinas pendidikan kabupaten/ kota, yaitu dengan proporsi kepala sekolah yang menjawab sebesar 29\% dari 127 responden kepala sekolah. Dari data tersebut terlihat bahwa kegiatan monitoring masih rendah karena belum ada separuh dari sekolah sampel yang pernah dimonitor dan dievaluasi hingga bulan September 2014. Ada beberapa kemungkinan penyebab rendahnya kegiatan monitoring 
implementasi Kurikulum 2013, antara lain belum semua sekolah menerima atau melaksanakan aspek yang dimonitor. Sebagai contoh, banyak sekolah yang belum menerima baik buku siswa maupun buku guru, sehingga kegiatan monitoring tidak bisa dilaksanakan. Kemungkinan lain, masih banyak guru yang belum mengikuti pelatihan sehingga monitoring juga belum bisa dilaksanakan.

Secara keseluruhan dapat disimpulkan bahwa sekolah yang telah dimonitor dalam implementasi Kurikulum 2013, baik oleh Kemdikbud, dinas pendidikan provinsi, maupun dinas pendidikan kabupaten/kota, proporsinya masih rendah. Proporsi sekolah yang dimonitor oleh dinas pendidikan kabupaten/kota kurang dari $40 \%$, oleh disdikprov dibawah $20 \%$, dan oleh Kemdikbud tidak lebih dari 22\%. Namun, jika data tersebut dibandingkan antarketiga instansi, tampak bahwa dinas pendidikan kabupaten/kota memiliki peran paling besar dalam melakukan monitoring ke sekolah-sekolah dibandingkan dengan dinas pendidikan provinsi, dan Kemdikbud. Sementara itu, pelaksanaan monitoring di tingkat dinas pendidikan kabupaten/kota melihat pada aspek-aspek seperti dalam Tabel 6.

Berdasarkan data tersebut, dinas pendidikan kabupaten/kota paling banyak melakukan monitoring pada aspek sosialisasi dan aspek pelatihan guru, yaitu masing-masing 6 kabupaten/kota dari 10 kabupaten/kota (60\%), sedangkan yang paling rendah ialah monitoring pada aspek pelatihan pengawas, konten buku, dan pelaksanaan kurikulum di sekolah yakni masing-masing 3 dari 10 kabupaten/kota (30\%). Sementara itu, untuk aspek yang paling sering dilakukan dalam monitoring ditemukan pada aspek sosialisasi, yaitu rata-rata 4 kali dengan kisaran 1 hingga 9 kali. Selanjutnya, aspek pelatihan guru yaitu rata-rata 3 sampai 4 kali, pengadaan buku rata-rata 2 sampai 3 kali, pelatihan kepala sekolah rata-rata 2 kali, dan pelatihan pengawas, konten buku, serta

Tabel 6 Monitor dan Evaluasi di Tingkat Sekolah

\begin{tabular}{llcccc}
\hline & Yang melakukan & \multicolumn{3}{c}{ Komponen yang dimonitor dan dievaluasi (dalam \%) } \\
\cline { 3 - 6 } No. & monitor dan evaluasi & Buku siswa & Buku guru & PBM & pendampingan \\
\hline 1. & Kemendikbud & 20,5 & 22 & 13,4 & 10,2 \\
2. & $\begin{array}{l}\text { Dinas pendidikan } \\
\text { provinsi }\end{array}$ & 15 & 17,3 & 15 & 10,2 \\
3. & $\begin{array}{l}\text { Dinas pendidikan } \\
\text { kabupaten/kota }\end{array}$ & 39,4 & 36,2 & 38,6 & 28,3 \\
4. & Pihak lain & 3,9 & 5,5 & 6,3 & 5,5 \\
\hline
\end{tabular}

Tabel 7 Monitoring di Tingkat Dinas Pendidikan $(\mathrm{N}=10)$

\begin{tabular}{llcccc}
\hline No. & Aspek Yang di Monev & Ya & Tidak & Tidak menjawab & Rata-rata (Kali) \\
\hline 1. & Sosialisasi & 6 & 1 & 3 & 4 \\
2. & Pelatihan guru & 6 & 1 & 3 & 3,5 \\
3. & Pelatihan Kep.sek & 5 & 1 & 4 & 1,5 \\
4. & Pelatihan pengawas & 3 & 1 & 6 & 1 \\
5. & Pengadaan Buku*) & 4 & 2 & 4 & 2,5 \\
6. & Konten buku & 3 & 2 & 5 & 1 \\
7. & Pelaksanaan K.13 di sekolah & 3 & 1 & 6 & 1 \\
\hline
\end{tabular}

Catatan*) Enam kabupaten/kota belum menerima buku 
pelaksanaan kurikulum di sekolah masing-masing memiliki rata-rata 1 kali.

Kegiatan monitoring implementasi Kurikulum 2013 oleh dinas pendidikan kabupaten/kota pada umumnya mengikuti program yang telah ditentukan oleh Pusat yang dibantu unit pelaksana teknis Pusat di berbagai daerah (LPMP, P4TK). Instrumen monitoring dibuat oleh penyelenggara program, sedangkan pelaksana monitoring, selain penyelenggara program juga melibatkan pihak-pihak lain yaitu: pejabat/staf dinas pendidikan, dan para pengawas. Misalnya di Kabupaten Kutai Kartanegara, monitoring yang diprogramkan LPMP telah dilaksanakan, yaitu dengan menyasar secara sampling guru pelaksana sebanyak 2.000 orang atas inisiatif dari pengawas. Dengan metode seperti itu, pada bulan Juli 2014 telah dimonitoring sebanyak 200 guru pelaksana dari semua satuan pendidikan.

Sementara itu, dinas pendidikan kabupaten/ kota belum ada yang secara mandiri melakukan monitoring dengan menggunakan acuan dan instrumen baku dari Pusat, serta memakai kaidah ilmiah (menyusun desain dan instrumen, metode ilmiah, pengolahan dan analisis data, serta pelaporan dan penyampaian hasil). Monitoring dan evaluasi yang secara mandiri dilakukan oleh dinas pendidikan kabupaten/kota pada umumnya dibantu oleh para pengawas di wilayah binaannya masing-masing dengan hanya melihat-lihat, karena itu merupakan bagian dari tugas seorang pengawas. Misalnya, dari hasil kunjungan Pengawas ditemukan bahwa dari jumlah guru 100 orang, ternyata baru 70 orang yang telah dilatih tentang Kurikulum 2013. Selain itu, pihak sekolah, dan komite sekolah juga nampak belum secara spesifik melaksanakan monitoring tentang Kurikulum 2013. Mereka umumnya melaksanakan monitoring Kurikulum 2013 atas dasar tugasnya masing-masing, yaitu: kepala sekolah melalui tugas supervisi kepada guru-guru di setiap kelas dan pihak komite sekolah dalam rangka membantu pihak sekolah untuk kelancaran program sekolah.

Monitoring dan evaluasi merupakan tahap yang penting, karena hasil monitoring akan digunakan sebagai bahan evalusi dalam pelaksanaan kurikulum. Melalui evalusi kurikulum yang memenuhi prosedur dan ketentuan yang telah dirumuskan, pembenahan pendidikan dalam berbagai dimensinya akan memiliki landasan yang lebih kukuh dalam pertanggungjawaban efektivitas dan kebermaknaan kurikulum sebagai media pengembangan sumber daya manusia (Musanna, 2012). Dalam kerangka desentralisasi, pemerintah daerah mempunyai kepentingan yang sangat tinggi akan hasil evalusai karena hasil ini bisa digunakan untuk meningkatkan dan mengembangkan secara lebih rinci kurikulum sesuai dengan tuntutan kebutuhan daerah dan memungkinkan daerah untuk mengembangkan divesifikasi kurikulum (Sucipto, 2015:-).

\section{SIMPULAN DAN SARAN \\ Simpulan}

Dalam penerapan Kurikulum 2013 pemerintah daerah berperan dalam bentuk dukungandukungan yang mereka berikan. Pertama, Pemerintah daerah (dinas pendidikan provinsi dan dinas pendidikan kabupaten/kota), dan lembaga lain seperti LPMP dan P4TK secara aktif terlibat dalam melakukan sosialisasi Kurikulum 2013 kepada guru, kepala sekolah, dan berbagai forum, antara lain rapat dinas, workshop, seminar, pelatihan, kegiatan kelompok kerja guru (KKG), musyawarah guru mata pelajaran (MGMP), kelompok kerja kepala sekolah (K3S), forum pengawas (Forwas) yang dibiayai dari berbagai sumber, antara lain pemerintah daerah, komite sekolah, sekolah, dan mandiri.

Kedua, pemerintah daerah juga berperan dalam melaksanakan pelatihan Kurikulum 2013 guru, kepala sekolah dan pengawas. Beberapa kabupaten/kota mengalokasikan dana khusus yang cukup besar untuk pelatihan. Demikian juga beberapa pihak yang berkepentingan, seperti yayasan pendidikan swasta berperan mengadakan pelatihan agar terjadi perubahan mindset dan strategi pembelajaran sesuai dengan tuntutan Kurikulum 2013. Pemerintah daerah juga memberdayakan kepala sekolah dan 
guru dari sekolah piloting Kurikulum 2013 untuk melatih kepala sekolah dan guru lain yang belum dilatih melalui berbagai forum seperti MGMP, KKG dan K3S. Dalam diklat tersebut umumnya disampaikan materi tentang pembelajaran tematik terpadu, proses pembelajaran saintifik, menyusun RPP, penilaian belajar, dan tata cara pengisian rapor.

Ketiga, pemerintah daerah kurang berperan dalam pengadaan dan distribusi buku sampai ke sekolah, karena terbatasnya kewenangan pemerintah daerah dalam pengadaan dan distribusi buku. Pengadaan dan distribusi buku Kurikulum 2013 ditangani secara terpusat, mulai dari penyusunan buku, tata cara pelelangan, penetapan pemenang lelang, penggandaan buku, penggunaan dana untuk pembelian buku, dan pendistribusian buku hingga ke sekolah. Pemerintah daerah dalam hal ini hanya mengoordinir tentang berapa jumlah dan jenis buku yang dipesan sekolah, kapan akan dikirim oleh penyedia buku, dan menjadi penghubung dengan pihak penyedia buku. Peran daerah menjadi sangat penting ketika terjadi keterlambatan distribusi buku. Pemerintah daerah berperan dalam menyediakan dan menggandakan bahan pembelajaran dari $C D$ dan/ atau buku master bagi sekolah yang belum menerima buku dari penerbit tepat pada waktunya, padahal pembelajaran harus dilaksanakan.

Dalam pelaksanaan Kurikulum 2013 pemda telah mengalokasikan dana dari APBD dengan jumlah yang bervariasi, yaitu berkisar antara Rp 400 juta sampai dengan Rp 2,5 milyar. Dana tersebut digunakan untuk sosialisasi, menuntaskan diklat kepala sekolah, guru dan pengawas, serta pendampingan dan monitoring dan evaluasi Kurikulum 2013. Pengeluaran dana untuk implementasi Kurikulm 2013 juga dilakukan oleh berbagai pengurus MGMP, KKG, K3S, Forwas, serta yayasan pendidikan. Selain itu, sekolah juga berperan dalam pendanaan, terutama untuk biaya fotokopi maupun penggandaan bahan pembelajaran, baik buku master maupun Compact Disc.
Keempat, peran pemerintah daerah dalam pendanaan implementasi Kurikulum 2013 terlihat pada tahun ke dua, yaitu dengan alokasi APBD yang disiapkan oleh pemeintah daerah. Kontribusi dana yang disediakan oleh pemerintah daerah bervariasi dari penyediaan dana hingga menyediakan fasilitas untuk pelatihan guru. Secara umum, dana yang disediakan oleh pemerintah daerah digunakan untuk pelatihan guru, karena masih banyak guru yang belum mengikuti pelatihan.

Terakhir, Dinas pendidikan kabupaten/kota melaksanakan monitor dan evaluasi implementasi Kurikulum 2013 baik terhadap satuan pendidikan yang melaksanakan Kurikulum 2013 pada tahun 2013 maupun pada tahun 2014. Kegiatan tersebut dilakukan oleh pembina pendidikan dari dinas pendidikan, pengawas dan kepala sekolah. Berkaitan dengan monitoring dan evaluasi, belum seluruhnya memenuhi standar monev Kurikulum 2013, baik kompetensi petugas, sasaran monitoring dan evaluasi, instrumentasi, strategi pelaksanan, maupun tindak lanjut monitoring dan evaluasi.

\section{Saran}

Pertama, agar K-13 dapat dimplementasikan secara menyeluruh pada tahun 2018 untuk seluruh satuan pendidikan, perlu memperkuat peran pemerintah daerah, terutama dinas pendidikan untuk melakukan sosialisasi dengan melibatkan pembina pendidikan, pengawas, kepala sekolah melalui berbagai forum, antara lain rapat dinas, workshop, seminar, diklat, kegiatan KKG, MGMP, K3S, Forum pengawas (Forwas); serta memberdayakan yayasan pendidikan. Sosialisasi merupakan tahap yang harus dilakukan agar proses implementasi bisa berjalan sesuai dengan target pencapaian.

Kedua, pemerintah provinsi dan pemerintah daerah kabupaten/kota, terutama dinas pendidikan perlu diberi keleluasaan dan didorong untuk mengimlementasikan Kurikulum 2013, khususnya pada pelaksanaan program diklat guru, kepala sekolah dan pengawas untuk mempercepat jangkauan sasaran sekolah yang 
melaksanakan Kurikulum 2013 dengan meningkatkan peran daerah melalui alokasi dana APBD, sumberdaya pendidik dan tenaga kependidikan, kemampuan merencanakan sasaran pelatihan serta motivasi pemerintah daerah dalam mengimplementasikan baik Kurikulum 2013. Diklat yang dilakukan harus memenuhi standar pelatihan Kurikulum 2013 mengenai waktu, materi, maupun kompetensi instrukturnya. Target penguasaan materi juga harus ditetapkan agar sasaran diklat tercapai. Diklat harus diberlakukan kepada semua guru dengan model raining of trainer (TOT) di tingkat kabupaten/ kota oleh Tim Pengembang Kurikulum (TPK) dan dinas pendidikan berperan untuk merekrut anggota TPK. Kemudian, LPMP dan atau unit yang relevan yang melatih mereka bersama dengan kepala sekolah dan pengawas. Setelah itu untuk diklat di kabupaten/kota bisa dilakukan oleh TPK.

Ketiga, pemerintah daerah (dinas pendidikan) dan pihak-pihak terkait di daerah perlu diberi kewenangan yang lebih besar dalam pengadaan dan distribusi buku Kurikulum 2013. misalnya dengan membentuk pusat pengadaan dan distribusi buku di setiap wilayah. Pusat tetap berwenang untuk merancang dan menyiapkan master buku Kurikulum 2013, serta melakukan pengadaan dan distribusi buku bagi daerahdaerah yang tidak mampu mengadakan dan mendistribusikan buku sampai ke satuan pendidikan. Adapun pemerintah daerah (provinsi/kabupaten/kota) atau kerja sama antara provinsi dan kabupaten/kota (dinas pendidikan) diberi kewenangan untuk mengatur tata cara dan melaksanakan pengadaan buku (pelelangan, penetapan pemenang lelang, dan penjaminan mutu buku) dan pendistribusian buku sampai ke satuan pendidikan.

Keempat, bagi daerah yang memiliki kemampuan fiskal tinggi, perlu meningkatkan perannya dalam rangka percepatan pelaksanaan Kurikulum 2013 (target 2018) untuk membiayai diklat, pengadaan dan pendistribusian buku, pendampingan, dan monitoring dan evaluasi. Sedangkan bagi daerah yang kurang mampu perlu diberi bantuan oleh Pusat, sehingga target pelaksanaan Kurikulum 2013 yang dicanangkan pemerintah tercapai.

Kelima, pemerintah kabupaten/kota, terutama dinas pendidikan, perlu meningkatkan perannya dalam melaksanakan monitoring dan evaluasi agar menjangkau seluruh sasaran satuan pendidikan dengan memberdayakan pembina pendidikan, pengawas dan kepala sekolah. Pelaksanaan monitoring dan evaluasi tersebut perlu memenuhi standar monitoring dan evaluasi Kurikulum 2013, baik kompetensi petugas, sasaran monitoring dan evaluasi, instrumentasi, strategi pelaksanan, maupun tindak lanjut monitoring dan evaluasi. Upaya yang ditempuh antara lain mengikutsertakan calon petugas dalam pelatihan monitoring dan evaluasi dan secara aktif memberikan feedback atas hasil monitoring dan evaluasi yang telah dilakukan, sehingga peningkatan kualitas pembelajaran dengan Kurikulum 2013 bisa dilakukan secara terus-menerus.

\section{PUSTAKA ACUAN}

Alawiyah, F. 2014. Kesiapan Guru Dalam Implementasi Kurikulum 2013. Info Singkat Kesejahteraan Sosial: Kajian Singkat Terhadap Isu-isu Terkini. VI(15), hlm. 9.

Budi, B. S. 2014. Strategi Guru Dalam Menghadapi Kurikulum 2013 di SMA Negeri 2 Surakarta. Skripsi. Surakarta: Universitas Sebelas Maret.

Clements, H. D. 2007. Curriculum Research: Toward a Framework for Research-Based Curricula. Journal for Research in Mathematic Education, 38(1) hlm. 35-70.

Hariana, R. 2015. Implementasi Program Kurikulum 2013 di SMP Negeri 7 Samarinda. Journal Administrasi Negara, 3 (5), hlm. 1727-1737. 
Jati, W. R. 2015. Bonus Demografi sebagai Mesin Pertumbuhan Ekonomi: Jendela Peluang dan Jendela Bencana di Indonesia. Populasi, 26( 1), hIm. 1-19.

Kementerian Pendidikan dan Kebudayaan. 2013. Peraturan Menteri Pendidikan dan Kebudayaan Nomor 81A Tahun 2013 tentang Implementasi Kurikulum. Jakarta: Kemdikbud.

Kementerian Pendidikan dan Kebudayaan. 2014. Implementasi Kurikulum 2013. Paparan Menteri Pendidikan dan Kebudayaan. Workshop, Pondok Cabe 14 Januari 2014.

Kementerian Pendidikan dan Kebudayaan. 2013. Peraturan Menteri Pendidikan dan Kebudayaan Nomor 67 Tahun 2013 tentang Kerangka Dasar Dan Struktur Kurikulum Sekolah Dasar/ Madrasah Ibtidaiyah. Jakarta: Kemdikbud.

Kementerian Keuangan. 2014. Peraturan Menteri Keuangan Republik Indonesia Nomor 34/ PMK.07/2014 tentang Peta Kapasitas Fiskal Daerah. Jakarta: Kemenkeu.

Musanna, A. 2012. Quo Vadis Praksis Evaluasi Kurikulum: Studi Pendahuluan terhadap Ranah Kurikulum yang Terlupakan. Jurnal Pendidikan dan Kebudayaan,18(1), hlm. 1-11.

OECD. 2014. PISA 2012 Result in Focus: What 15-year-olds Know and What They Can Do. OECD: Programme for International Student Assesment.

Simamora, B. 2014. Kajian terhadap Manajemen dan Penerbitan Buku Teks Pelajaran Kurikulum 2013. Jurnal Publipreneur, 2, (3), hlm. 1-14.

Sulistyani. 2014. Analisis Pembelajaran Ekonomi SMA Berbasis Kurikulum 2013 Se-Jawa Tengah. Journal of Economic Education (JEE, 3 (2).

Sutjipto. 2015. Diversifikasi Kurikulum Dalam Kerangka Desentralisasi Pendidikan. Jurnal Pendidikan dan Kebudayaan 21( 3), hlm. 317-338. 
Lucia H. Winingsih, Peran Pemerintah Daerah Dalam Implementasi Kurikulum 2013 